\title{
Significance: recognizing the value of research across national and linguistic boundaries
}

\author{
Kathryn M. Anderson-Levitt
}

Published online: 1 May 2014

(c) Education Research Institute, Seoul National University, Seoul, Korea 2014

\begin{abstract}
Internationalization of educational publishing promises fresh perspectives and new solutions-but not if US-based editors, reviewers, and readers fail to recognize the significance of research conducted outside the USA. This essay explores the concept of "significance" in the context of peer review of journal articles, and explains why US-based reviewers easily miss the social importance and the intellectual interest of research conducted elsewhere. It points to several steps that can be taken to increase publication of the full global range of educational scholarship.
\end{abstract}

Keywords Academic discourse communities .

Educational research - English for academic purposes .

Faculty publishing · Globalization - Intercultural

communication - Peer evaluation - Writing for publication

\section{Introduction}

This article concerns the kinds of judgments made by editors of "international" journals and their reviewers when together they decide whether a manuscript submitted to the journal merits publication. ${ }^{1}$ I address this discussion primarily to scholars who seek to publish in international journals, but also to editors of international journals who are concerned about issues of global equity in academic publishing.

The label "international" generally refers to "high impact" research journals published in a "world

K. M. Anderson-Levitt

University of Michigan-Dearborn, Dearborn, MI, USA

K. M. Anderson-Levitt ( $\square)$

UCLA, Los Angeles, CA, USA

e-mail: kandersonlevitt@ucla.edu language," which usually means English. While the Asia Pacific Education Review fits this definition, the majority of "journals with impact factor" are published in the USA. As of 2007, of the 113 education journals used by Thomson Reuters' Social Science Citation Index, 61 had originated in the USA, 37 in the UK, and 15 in other countries (Peters 2009: 243-244). Thus, this article will focus on US-based journals. $^{2}$

Non-US scholars seek to publish in US journals for at least two good reasons. First, like all scholars, they are seeking to reach a wider audience with their research. In addition, many of them are responding to pressure to publish in "high impact" journals (e.g., Larsson 2006: 192; Uzuner 2008). Not everyone accepts the measurement mania that feeds the latter pressure (e.g., Willinsky 2006), but it is real. For example, as Lillis and Curry show in an important study of the process by which manuscripts get accepted or rejected by "international" journals, evaluation guides for tenure and promotion from Spain, Hungary, and Slovakia give extra weight to "journals with impact factor" or to "PsychInfo or SCI" (Lillis and Curry 2010: 50-56).

\footnotetext{
1 An earlier version of this paper appears in the Education Policy Analysis Archives. The version presented here was developed for the 14th annual meeting of the International Conference on Education Research at Seoul National University. I am grateful for the opportunity to have participated in that conference.

2 Here "US journals" means peer-reviewed periodicals whose editors usually come from US universities, whatever the location of the publisher, and "non-US scholars" means scholars who work in institutions outside the United States, excluding US-born and educated expatriates. There are actually many degrees of "inside" and "outside," so that scholars who received doctoral education in the United States but now work outside it have some insider knowledge of the USA, while non-native English speakers who were educated elsewhere but now work inside the United States may face linguistic challenges.
} 
Table 1 Criteria for review: example of the Comparative Education Review's questions to reviewers

Quality
"Is the manuscript grounded appropriately in a methodological
literature?"
"If the contribution draws on empirical research, are its
procedures and data clearly described and are they appropriate
for the purposes of the paper?"
Clarity
"How would you rate the clarity of the writing and its
accessibility to CER readers?"
Significance
"How relevant is the piece to the field of comparative and
international education?"
"Is the manuscript grounded in an appropriate theoretical/
conceptual literature?"
"How important is the piece as a contribution to theory and
research?"
"How important is it to the advancement of policy and
practice?"

The drive to publish in international journals takes place within an increasingly global arena of educational research. For example, in 2009, educational research associations from Japan, Korea, Hong Kong, the United States, and 20 other polities founded the World Educational Research Association (http://www.weraonline.org/). The dialog within this association of associations holds an exciting promise for rich, multilingual, variegated ways of framing educational problems, and equally diverse practical solutions, and theoretical tools. However, in the current context of unequal access to "international" journals and of citation indexing biased in favor of US journals, the move to a global arena also poses a real danger that research will become yet more narrowly filtered by the interests of English speakers and particularly by US-based editors, reviewers, and readers. This paper will illustrate how such filtering happens by examining one of the criteria faced by non-US authors who seek to publish in US journals, namely, judgments about the "significance" of their manuscripts.

When a manuscript goes to a peer-reviewed journal, editors, and reviewers refer to several kinds of criteria to evaluate it. These criteria tend to cluster around three basic norms-quality of the research, clarity, and significance. Table 1 illustrates with the case of the journal Comparative Education Review, showing how the guiding questions that the journal asks reviewers to address when evaluating a manuscript cluster around these three norms.

Quality of the research is a minimum requirement for all authors, although it may be more difficult for scholars from lower-income countries to meet this requirement if they lack access to the full range of prior research on their topic, if they have had fewer opportunities for advanced training in research methods, or if they lack the financial resources to carry out more sophisticated research projects (Canagarajah 1996; Mweru 2010). Clarity refers not only to word choice and the flow of sentences and paragraphs, but also to the rhetorical structure of arguments as taken for granted by particular disciplines in the USA (Bazerman 1988; Flowerdew 2008; Ollion 2011: appendix). The criterion of clarity, although of lesser importance than quality, is a hurdle for authors who are not native speakers of English, whether they work in a developing or a developed country (e.g., Uzuner 2008), and becomes a serious problem if lack of clarity makes it difficult for reviewers to follow the author's argument. Finally, even scholars who work in affluent countries and are native speakers of English can encounter hidden barriers when editors and reviewers make judgments about the significance of their research.

\section{Significance}

Significance means why a particular study matters, that is, what makes it worth reading or what it contributes to theory or practice. Thus, the Educational Researcher, a flagship journal of the American Educational Research Association (AERA), seeks feature articles and reviews or essays "of broad significance" ("Manuscript submission," http://edr.sagepub.com/), while AERA's American Educational Research Journal publishes studies and analyses "that constitute significant contributions to the understanding and/or improvement of educational processes and outcomes" ("Manuscript submission," http://aer.sagepub. com/). Similarly, in a study of the peer-review process for allocating grants in the social sciences and humanities, significance was not only a formal criterion established by the granting agencies but also the criterion mentioned most often in interviews by the scholars conducting the reviews (Lamont 2009).

I address the question of significance from the perspective of a US-born former editor and current co-editor of US journals who has struggled myself with recognizing the value of unfamiliar work. ${ }^{3}$ As an editor, I have told authors that, since journals receive so many manuscripts based on high-quality research with fairly clear writing, the most important criterion for accepting a manuscript is usually the significance of the work.

When peer reviewers and editors assess the significance of a scholarly work, they actually make two kinds of judgments, one about "social/political" significance and

\footnotetext{
3 I served as editor of the US-based Anthropology and Education Quarterly in 1994-2000, and currently serve as one of the co-editors of the US-based Comparative Education Review.
} 
one about "scholarly" significance (Lamont 2009: 160). In the first case, they ask whether a work is what I will gloss as "important," that is, whether it addresses the most pressing problems we need to face as members of society. In the second case, reviewers ask whether a work is what I will call "interesting," that is, whether the ideas it presents are stimulating or provocative, whether they "advance the field." These are, of course, overlapping categories; a topic may be both important and interesting, or may be considered interesting precisely because it is important. However, because the context of judgments about what is important differs from the context shaping discussions of what is interesting, I discuss these two dimensions separately here.

What counts as important

Reviewers favor studies addressing real and immediate social problems, not only in applied fields like education but across the social sciences and humanities (Lamont 2009: 172). However, norms for judging what counts as important problems often depend on nation- and regionspecific social and political contexts, as illustrated by crossnational variation in the most popular research topics. For example, within anthropology of education, US scholars focus on success and failure among racialized/ethnic and linguistic "minorities" (Delamont and Atkinson 1995; Jacquin 2006). There are good reasons for the US focus, including a history marked by conquest of indigenous peoples and Africans, waves of immigration and persisting inequalities. However, seen from Mexico, the US word "minority" does not make sense, because anthropologists there are concerned with equity for the majority of the school-aged population (Rockwell 2002). Elsewhere, ethnographers are more likely to focus on social class, as in France, where legislation discourages attention to ethnicity (Raveaud and Draelants 2011), or to examine inequities defined by local social and historical processes, including migration from the South in Italy (Gobbo 2011) or minoritized Roma populations in Central Europe (Eröss 2011). In developing countries, external actors may drive the equity concerns, as when interests of the World Bank and USAID give gender equity more prominence as a topic in West Africa than it receives in the USA (Diallo 2011).

Not only topic per se but the location where the research took place also affects judgments about its importance. Thus, a study of journal articles in the field of economics showed that the top five journals (two of which are UK-based and three US-based) overwhelmingly favored studies that had been conducted in the USA (Das et al. 2009). The chance of acceptance for papers about India, China, and African nations or even about the United Kingdom was so much lower than the chance for a paper about the United States that deciding where to conduct one's research might actually affect a researcher's chances for tenure, according to the analysts (Das et al. 2009). Lillis and Curry (2010) suggest an explanation for these findings. They point out US reviewers' unstated assumption that the United States stands for the whole world, representing the "unmarked" or generic case, whereas other locations are seen as "marked" or particular. In their study of the publishing experiences of European psychologists and educational researchers, they found that reviewers wrote evaluative comments like, "Why did the authors choose to study Hungarian students?" or "Please could they outline why Madrid was chosen as the place of study..." (Lillis and Curry 2010: 142), whereas the reviewers would probably not have questioned studies set in California or New York City.

National differences in what counts as "important" research mean that reviewers are more likely to question the value of a study on a topic or location that they do not see as central to their own part of the world. As a result, in advice to authors and in decisions about whether to recommend publication, reviewers sometimes steer the literature to focus on problems that the reviewers, not the authors, see as important. Thus, Lillis and Curry found that editors occasionally encouraged the authors of studies set elsewhere to develop an explicit comparison to US literature so that the non-US location, with its "difference" explicitly highlighted, could be used to confirm the presumably generic US findings (2010: 145-147). Not surprising, anticipating that pressure, some non-US scholars filter themselves, as illustrated by a seminar in Spain on how to publish in "journals with impact" in which the speaker advised colleagues to "change the topic" and "approach the topic from an international perspective" (Robinson-García 2012: slides 25 and 48). Yet "an international perspective" can turn out to mean issues as they are defined locally within the USA.

\section{What counts as interesting}

Even in an applied field, reviewers and editors consider not only the practical importance but also the scholarly interest of a work. Journals sometimes discuss this criterion as "contribution to the advancement of knowledge." For example, recent Anthropology and Education Quarterly reviewer guidelines include among the criteria "potential impact on research and practice" and "significance of the topic for advancing the field of educational anthropology," while the Reading Research Quarterly advises authors that it seeks "manuscripts that make significant contributions to advancing knowledge and understanding of reading and of literacy, broadly defined." The interest of a manuscript is also closely aligned with judgments about a work's "originality" (Lamont 2009) and "novelty" (Lillis et al. 2010). 
Judgments about what is interesting develop in ongoing "disciplinary conversations" (Bazerman 1988:145), conversations in which scholars engage when they present at conferences and comment on colleagues' presentations, when they meet to evaluate applications for promotion or for grants, and when they chat about academic issues in university corridors. The conversations extend to written discourse when published in articles, chapters, books, or blogs. Within these conversations in any particular discipline, certain terms come to take prominent roles; for example, terms such as "pedagogical," "readiness," and "outcomes" appear often in educational research conferences, in contrast to terms such as "metaphor," "bricolage," and "imbrication," heard frequently at anthropology meetings over the past decade. At the same time, scholars cite certain authors so frequently in disciplinary conversations that the authors come to form a canon. Over time, both key terms and canonical authors come to serve as shorthand references to entire points of view so that, within the relevant discipline one term, such as "Goffmanesque," or one reference to an author, such as Pierre Bourdieu, evokes a broad theoretical scenario to scholars who have participated in that conversation.

Linguistic barriers play a role in the disciplinary conversations that affect judgments about significance, since linguistic competence constrains who participates in which conversations within what is ostensibly the same discipline. Scholars in many countries are multilingual, and within their local disciplinary discourse community or speech community, it may be the norm to communicate in two, three, or more languages. In contrast, the social science disciplines in the USA operate as virtually monolingual, as can be demonstrated by our citation patterns (Gingras and Mosbah-Natanson 2010; Hewings et al. 2012; Yitzhaki 1998). This monolingualism, compounded by a low rate of book translation into English, isolates US readers from the conversations going on in other languages.

At the same time, linguistic competence is not the only constraint on disciplinary conversations. Citation patterns also reveal national and regional boundaries independent of linguistic borders (Yitzhaki 1998). For example, US ethnographers of education cite relatively little British ethnography of education (Delamont and Atkinson 1995), while neither British nor US scholars cite much from the large body of Scandinavian work published in English (Larsson 2006) or the large body of English-language educational research from India. National boundaries develop in part because disciplines are organized differently from one country to another. Thus, scholars in comparative education attribute the lack of mutual citation between leading German and French education journals not to linguistic barriers but rather to the fact that educational research is historical and hermeneutic in Germany but positivist in France (Schriewer and Keiner 1993). Even the names of disciplines and their scope vary significantly across nations; for example, the school-focused study of éducation in France does not correspond with the Danish interest in all things paedagogik, that is, the "moral, social, and cultural formation" of persons across the lifespan (Anderson et al. 2011: 195), nor does an interest in "didactics" in continental Europe translate easily to the USA (Alexander 2001; see also Ouyang 2011).

Whether constrained by linguistic barriers or shaped by national differences, where distinct conversations take place even within the same discipline or family of disciplines, distinct canons and concepts emerge. As a result, even in a country like France, which imports and translates much more foreign social science than does the United States (Sapiro 2008), practitioners of a discipline like sociology remain relatively ignorant of the outline of sociology as practiced in the USA (Ollion 2011). Meanwhile, a mere reference to Bernard Lahire in France speaks volumes to sociologists of education there, while drawing blank looks from their US counterparts, just as the canonical significance of a scholar like Florestan Fernandes in Brazil or of Ebuchi Kazuhiro in Japan escapes US readers (Anderson-Levitt 2011). Imagine, then, how easily the significance of a particular citation or of a particular term in a manuscript could escape a reviewer or editor from outside that particular academic community. It is difficult for a reviewer to recognize how an argument "advances the field," when the field in question is not really the same as the reviewer's field.

Missing the significance has real effects in a world dominated by US journals. For example, sometimes reviewers, hoping to enhance a manuscript's perceived significance, press authors to restrict their citations to English-language literature. In doing so, they render relevant literature published in other languages nearly invisible (Hewings et al. 2012; compare Canagarajah 1996). In the most dramatic cases, reviewers may dismiss outright an entire body of research from another country, as in the European and US reaction to Japanese research in the field of primatology (Asquith 1999).

\section{Summary}

In short, editors, reviewers, and readers can easily miss the significance of research conducted in other parts of the world for two reasons-because they are unfamiliar with the social and historical context that makes the problems studied important and because they do not participate in the linguistically and nationally bounded conversations that define the author's questions as interesting. As a result, unless US editors change their practice, they-we-will continue to publish supposedly "international" journals 
that actually conform to the sensibilities of a surprisingly parochial US-based social science. How ironic it would be, given our desire for interesting, "new" and "original" ideas, to keep screening out the arguments that least fit within our current paradigms and therefore ought to be seen as the most novel (Lillis and Curry 2010: 167). And how limiting, when addressing the most important problems, to continue to let our vision be hemmed in by our local assumptions about the way schooling has to work or about how students learn. What new solutions to our pressing problems would we find if we reconceived inequity as a problem for the majority of the world's children, as in Mexico, or paid more attention to the moral side of education, as in Denmark?

\section{Changing the current practice}

I suggest possible remedies in the following paragraphs. Although the onus for change should be on US editors and reviewers, I will also comment on actions that editors and scholars in Asia and the Pacific might take on their part to improve mutual understanding of one another's research.

\section{Expanding indexes}

To address the larger problem of US and English-language dominance and the distortions created by the obsession with indexes measuring "impact," scholars and policy makers around the world are taking a number of actions. Many are developing open access repositories and journals, such as the Education Policy Analysis Archives, which can dramatically expand access to and citation of scholarly work (Willinsky 2006: 29-30). Universities and national resource centers have developed alternative indices such as Latindex (www.latindex.org), the Scientific Electronic Library Online (SciELO, www.scielo.org), the Chinese Social Sciences Index ( $\mathrm{Su}$ et al. 2012), the CJP in Japan (Negishi et al. 2004), and the Korea Citation Index (Ko et al. 2011). These efforts can lead to new ways to measure impact that rely less on US and UK standards (Fischman et al. 2010; Ko et al. 2011).

As part of the larger efforts, US scholars can make use of indexes beyond Web of Knowledge and Scopus when called on to review colleagues for tenure and promotion and can take advantage of open-source peer-reviewed research.

\section{Internationalizing editorial boards}

Meanwhile, some editors of US-based journals have increased the presence of non-US scholars on editorial boards with the idea that such scholars can function as cultural brokers, interpreting to editors the importance and interest of manuscripts submitted from discourse communities outside the USA. The success of such efforts will depend on how actively the cultural brokers intervene and how willing the editor is to take their advice. At the same time, some Asian and Pacific journals have internationalized their own editorial boards, thus making outside scholars who serve on their boards more familiar with topics, methods, and research literatures cited in their journals. However, as a study of Korean journals in the natural sciences reminds us, internationalizing boards will not necessarily have an effect on the international visibility of the journal or its authors' work, at least not in the short run (Kim 2010).

\section{Educating non-US authors}

Much more pro-actively, US editors can choose to educate authors about the expectations of "international" journals, as do editors of the British educational journal Compare. In Compare's program, "inside experts" mentor experienced scholars from the global South on "the specific disciplinary conversations that the journal wants to encourage; the implicit ideology of the journal in relation to what counts as a 'relevant' contribution to knowledge; what counts as 'new' within this particular journal" (Lillis et al. 2010: 785). Individual scholars in Asia and the Pacific can likewise seek to educate themselves about the norms of USbased journals. For example, large conferences like the annual meeting of the American Educational Research Association offer workshops and roundtables on publishing in specific US journals.

However, as facilitators of the Compare program recognize, helping writers meet the expectations of their reviewers does not "challenge dominant practices" (Lillis et al. 2010: 79). A better model would be the approach taken by the Croatian Medical Journal, where editors not only educate authors before they submit articles for review, but also address larger inequities by committing to publish research from developing countries on topics of interest in the authors' countries but not to "the mainstream journal audience" (Mišak et al. 2005: 124).

As for individual scholars, when they understand the peer-review process of "international" journals, they may be better prepared to argue for the "local content" of their manuscripts. Consider an author whose manuscript has made it through the first round of review and are invited to resubmit a revised manuscript. If reviewers have questioned the citation of works that are not in English, rather than eliminate the citations, the author might add English translations of the titles of the works in brackets, direct readers to English-language abstracts of the works when they exist and, in the cover letter to the editor, gently 
explain that a particular non-English citation is important and much cited in their part of the world. Some editors and reviewers will respond positively to humble but firm responses on a few points the authors show themselves ready to adapt to other suggestions from reviewers.

\section{Educating US reviewers}

Meanwhile, to understand and appreciate the topics important in other countries and key citations in other languages, US reviewers need to seek broader contextual knowledge. To contextualize, we must become wider readers. US journal editors can help with the task of broadening readers' horizons, as Comparative Education Review does by publishing an annual bibliography of worldwide (English-language) articles in the field, and as the French journal Education Comparée does by publishing the tables of contents of other French- and English-language journals.

US readers can also take action as individuals to educate themselves, especially now that electronic technologies make it much easier to follow publications outside the USA. Readers can sign up for free table of content alerts from many parts of the world-for example, from Frenchlanguage journals like Education et Sociétés at portals like Cairn (http://www.cairn.info/) and the Centre for Open Electronic publishing (http://www.revues.org/), or from Spanish journals at the government-sponsored Repositorio Español de Ciencia y Tecnología (http://recyt.fecyt.es/ index.php/index/login). To follow books on education, we can subscribe to the long-standing Spanish and Portuguese version of the open access electronic journal Education Review/Reseñas Educativas (http://www.edrev.info/).

Even readers who are monolingual in English can glean real insights from these approaches, since abstracts in English are often available and since programs like Google Translate can offer rough glosses of titles. However, to push beyond the literatures of the United Kingdom, Australia, and India, US readers should make the effort to read in languages other than English-and then to cite what they read in the original language as well as in English (Hamel 2007). By the same token, we should be rewarding multilingual colleagues and doctoral students for citing and for publishing in languages other than English. A next, albeit daunting, step would be to consider reinstating a foreign language-reading requirement in research-focused education doctorates.

There are also steps that US-based scholarly organizations can take. One is to support more translations of books, chapters, or articles from other languages into English. What US readers may need even more than translations, however, are periodic state-of-the-art reports synthesizing research from other countries or regions on particular topics, to help reviewers place individual manuscripts into their broader context. The American Anthropologist, prompted by the World Council of Anthropological Associations, has just committed to publishing review articles on work from outside the USA in a new section of the journal called "World Anthropology" (Weil 2013). Similarly, the Annual Review of Sociology seems to include syntheses from outside the USA fairly regularly. However, US handbooks in educational research less often include such reports from other countries.

Editors in Asia and the Pacific can support and encourage this kind of learning by US readers in at least two ways. First, journal editors should encourage their publishers to set up a system for RSS feed and email alert, as is available for the Asia Pacific Education Review. Second, Asian journals that publish in English can help by publishing occasional state-of-the-art essays. Such essays, if available through open access, could be publicized by the newsletters of "sister" organizations in the same field, such as the electronic newsletter of the Comparative and International Education Society.

Article exchanges: publishing articles reviewed "at home"

Editors of US journal could take a more radical step away from the filtering built into US-based reviews by occasionally accepting (and translating, if necessary) manuscripts that have already been reviewed and judged worthy of publication in the author's home country. For example, Educational Researcher might publish an article accepted but not published by the leading Brazilian journal, perhaps sending one of its accepted manuscripts to be published in Brazil in an exchange of pages. ${ }^{4}$ Ideally, editors or other cultural brokers would frame such externally reviewed articles with introductions providing a broader context to help US readers appreciate their significance. This is the kind of exchange that could be fostered through interactions across journals and professional organizations, as when representatives of KERA, JERA, and AERA meet through the World Educational Research Association.

\footnotetext{
${ }^{4}$ This is a solution suggested by journal editors from outside the United States in an open forum at the 2009 American Anthropological Association meeting. The International Political Science Association runs an entire journal, World Political Science Review, by publishing "translations of [already published] prize-winning articles nominated by prominent national political science associations and journals around the world" (http://www.degruyter.com/view/j/wpsr), but its system requires readers who deliberately seek out and pay for this transnational journal.
} 
Meeting at international conferences

Finally, paradoxical as it seems when open access on the Web and electronic alerts are part of the solution, we need to continue to encourage face-to-face meetings across national boundaries and to make more room in such meetings for communication across languages. Sometimes the solution can be as simple as inviting scholars to speak in their own languages (which we all do with more meaning-rich intonation and gestures than when reading a text in another language) while referring listeners to an outline in English. This is a practice tried with some success at a recent Inter-American Symposium on Ethnography and Education (http://conferences.gseis.ucla.edu/ simposio). Scholars in rhetoric point out that making convincing arguments in the social sciences requires a great deal of "personal credibility" (Hyland 2011: 203). Face-to-face interaction still offers the best opportunity to build trust in one another's scholarship and interest in one another's work, to the benefit of everyone in the worldwide field of educational research.

\section{References}

Alexander, R. J. (2001). Border crossings: Towards a comparative pedagogy. Comparative Education, 37(4), 507-523.

Anderson, S., Gulløv, E., \& Valentin, K. (2011). Educational anthropology in a welfare state perspective: The case of Scandinavia. In K. M. Anderson-Levitt (Ed.), Anthropologies of education (pp. 193-211). New York: Berghahn Books.

Anderson-Levitt, K. M. (2011). Anthropologies and ethnographies of education worldwide. In K. M. Anderson-Levitt (Ed.), Anthropologies of education: A global guide to ethnographic studies of learning and schooling (pp. 1-28). New York: Berghahn Books.

Asquith, P. J. (1999). The "world system" of anthropology and "professional others". In E. L. Cerroni-Long (Ed.), Anthropological theory in North America (pp. 33-53). Westport, CT: Bergin \& Garvey.

Bazerman, C. (1988). Shaping written knowledge. Madison, Wis.: University of Wisconsin Press. http://wac.colostate.edu/books/ bazerman_shaping/.

Canagarajah, A. S. (1996). "Nondiscursive" requirements in academic publishing, material resources of periphery scholars, and the politics of knowledge production. Written Communication, $13,435-472$.

Das, J., Do, Q.-T., Shaines, K., \& Srinivasan, S. (2009). U.S. and them: The geography of academic research. Policy research working paper 5152. Washington, DC: The World Bank. Development research group. Poverty and inequality team \& human development and public services team.

Delamont, S., \& Atkinson, P. (Eds.). (1995). Fighting familiarity: Essays on education and ethnography. Cresskill, NJ: Hampton Press.

Diallo, B. B. (2011). Sociological and ethnographic research in French-speaking sub-Saharan Africa. In K. Anderson-Levitt (Ed.), Anthropologies of education (pp. 279-302). New York: Berghahn Books.
Eröss, G. (2011). Central Europe (Bulgaria, Czech Republic, Hungary, Poland, Romania, Slovakia). In K. Anderson-Levitt (Ed.), Anthropologies of education (pp. 151-166). New York: Berghahn Books.

Fischman, G. E., Alperin, J. P., \& Willinsky, J. (2010). Visibility and quality in Spanish-language Latin American scholarly publishing. Information technologies \& international development, 6(4). http://itidjournal.org/itid/article/viewArticle/639).

Flowerdew, J. (2008). Scholarly writers who use English as an additional language: What can Goffman's "Stigma" tell us? Journal of English for Academic Purposes, 7, 77-86.

Gingras, Y., \& Mosbah-Natanson, S. (2010). Where are social sciences produced? In UNESCO (Ed.), World social science report (pp. 149-153). Paris: UNESCO \& International Social Science Council.

Gobbo, F. (2011). Anthropology of education in Italy. In K. Anderson-Levitt (Ed.), Mapping anthropologies of education (pp. 151-165). New York: Berghahn Books.

Hamel, R. E. (2007). The dominance of English in the international scientific periodical literature and the future of language use in science. AILA Review, 20, 53-71.

Hewings, A., Lillis, T., \& Vladimirou, D. (2012). Who's citing whose writings? Journal of English for Academic Purposes, 9, $102-115$.

Hyland, K. (2011). Disciplines and discourses: Social interactions in the construction of knowledge. In D. Starke-Meyerring, A. Paré, N. Artemeva, M. Horne, \& L. Yousoubova (Eds.), Writing in knowledge societies. Fort Collins, CO: The WAC Clearinghouse and Parlor Press.

Jacquin, M. (2006). La revue anthropology and education quarterly. Analyse des dix dernières années. Éducation et Sociétés, 17, 89-104.

Kim, M.-J. (2010). Visibility of Korean science journals: An analysis between citation measures among international composition of editorial board and foreign authorship. Scientometrics, 84(2), 505-522. doi:10.1007/s11192-010-0168-x.

Ko, Y., Cho, S.-R., \& Park, Y. (2011). A study on the optimization of KCI-based index (Kor-Factor) in evaluating Korean journals. Scientometrics, 88(1), 61-71. doi:10.1007/s11192-011-0384-z.

Lamont, M. (2009). How professors think: Inside the curious world of academic judgment. Cambridge: Harvard University Press.

Larsson, S. (2006). Ethnography in action. How ethnography was established in Swedish educational research. Ethnography and Education, 1, 177-195.

Lillis, T. M., \& Curry, M. J. (2010). Academic writing in a global context: The politics and practices of publishing in English. New York: Routledge.

Lillis, T. M., Magyar, A., \& Robinson-Pant, A. (2010). An international journal's attempts to address inequalities in academic publishing: Developing a writing for publication programme. Compare, 40(6), 781-800.

Mišak, A., Marušić, M., \& Marušić, A. (2005). Manuscript editing as a way of teaching academic writing: Experience from a small scientific journal. Journal of Second Language Writing, 14(2), 122-131. doi:10.1016/j.jslw.2005.05.001.

Mweru, M. (2010). Why Kenyan academics do not publish in international refereed journals. In UNESCO (Ed.), World social science report (pp. 110-111). Paris: UNESCO \& International Social Science Council.

Negishi, M., Sun, Y., \& Shigi, K. (2004). Citation database for Japanese papers: A new bibliometric tool for Japanese academic society. Scientometrics, 60(3), 333-351. doi:10.1023/B:SCIE. 0000034378.38698.b2.

Ollion, É. (2011). De la sociologie en Amérique. Éléments pour une sociologie de la sociologie étasunienne contemporaine. Sociologie, 2(3), 277-294. 
Ouyang, H. (2011). Bamboo shoots after rain: Educational anthropology and ethnography in Mainland China. In K. AndersonLevitt (Ed.), Anthropologies of education (pp. 235-255). New York: Berghahn Books.

Peters, M. A. (2009). Academic publishing and the political economy of education journals. In B. W. Cope \& A. Phillips (Eds.), The future of the academic journal. Oxford: Chandos Publishing.

Raveaud, M., \& Draelants, H. (2011). Ethnographies of education in the French-speaking world. In K. M. Anderson-Levitt (Ed.), Anthropologies of education (pp. 131-149). New York: Berghahn Books.

Robinson-García, N. (2012). How to publish in journals with impact? Retrieved July 19, 2012, from http://www.slideshare.net/figaro/ how-to-publish-in-journals-with-impact.

Rockwell, E. (2002). Constructing diversity and civility in the United States and Latin America. In B. A. U. Levinson, S. L. Cade, A. Padawer, \& A. P. Elvir (Eds.), Ethnography and educational policy across the Americas (pp. 3-19). Westport, CT: Praeger/ Greenwood.
Sapiro, G. (2008). Translatio. Le marché de la traduction en France à l'heure de la mondialisation. Paris: CNRS.

Schriewer, J., \& Keiner, E. (1993). Communication patterns and intellectual traditions in educational sciences: France and Germany. Comparative Education Review, 36, 25-51.

Su, X., Deng, S., \& Shen, S. (2012). The design and application value of the Chinese Social Science Citation Index. Scientometrics, 98, 1567-1582. doi:10.1007/s11192-012-0921-4.

Uzuner, S. (2008). Multilingual scholars' participation in core/global academic communities: A literature review. Journal of English for Academic Purposes, 7(4), 250-263.

Weil, J. (2013). The world anthropology section: An introduction. American Anthropologist, 115(4), 656-657. doi:10.1111/aman.12054.

Willinsky, J. (2006). The access principle: The case for open access to research and scholarship. Cambridge, MA: MIT Press.

Yitzhaki, M. (1998). The 'language preference' in sociology: Measures of 'language self-citation', 'relative own-language preference indicator', and 'mutual use of languages'. Scientometrics, 41, 243-254. 